\title{
Association of acute parvovirus B19 infection with new onset of acute lymphoblastic and myeloblastic leukaemia
}

\author{
J R Kerr, F Barah, V S Cunniffe, J Smith, P J Vallely, A M Will, R F Wynn, R F Stevens, G M Taylor, \\ G M Cleator, O B Eden
}

Aims: To investigate the association of acute parvovirus B19 infection with new onset of acute lymphoblastic and myeloblastic leukaemia.

Methods: Cerebrospinal fluid (CSF) samples from patients with acute myelogenous leukaemia (AML) at diagnosis ( $n=2$ ) and acute lymphoblastic leukaemia (ALL) at diagnosis ( $n=14$ ) were analysed for parvovirus B19 DNA by means of nested polymerase chain reaction. In addition, samples from patients with benign intracranial hypertension (BIH) $(n=10)$ and hydrocephalus $(n=13)$ were tested as controls.

Results: Four leukaemia cases were positive-common ALL $(\mathrm{n}=2)$, null cell ALL $(\mathrm{n}=1)$, and M7 AML $(\mathrm{n}=1)-$ whereas all controls were negative (Yates corrected $\chi^{2}$ value, $3.97 ; p=0.046$; odds ratio, 16.92 ; confidence interval, 1.03 to 77.18$)$. All four patients were significantly anaemic, but none was encephalitic or had evidence of central nervous system leukaemia. In three of these patients, serum tumour necrosis $\alpha$, interferon $\gamma$, interleukin 6 , granulocyte-macrophage colony stimulating factor (range, 34.93-3800.06 $\mathrm{pg} / \mathrm{ml}$ ), and macrophage chemoattractant protein 1 were detectable. All of these four patients carried at least one of the HLA-DRB1 alleles, which have been associated with symptomatic parvovirus B19 infection.

Conclusion: Erythroid suppression and immune cell proliferation are both associated with B19 infection and may also be important in the pathogenesis of acute leukaemia.

$P$ arvovirus B19 is the aetiological agent of erythema infectiosum, transient bone marrow aplastic crises, arthritis, non-immune hydrops fetalis, and chronic pure red cell aplasia in immunocompromised persons. More than 20 reports describe an association between acute lymphoblastic leukaemia (ALL) and persistent B19 infection which, until recently, has been assumed to represent an opportunistic infection, the chronicity of which results from immunosuppression. However, several reports describe B19 infection preceding and mimicking ALL. ${ }^{1-4}$ One published study examined serum from 65 patients with ALL for B19 DNA and specific IgG. ${ }^{5}$ The results showed that although there was one positive case, which was also published separately, ${ }^{1}$ serum anti-B19 IgG was positive in $30 \%$ of patients, which is consistent with the population prevalence adjusted for age.

\section{"More than 20 reports describe an association between acute lymphoblastic leukaemia and persistent B19 infection"}

We hypothesised that if B19 virus does play a role in the pathogenesis of acute leukaemia, the virus may no longer be present in the serum at the time of diagnosis, but may be present at other more cryptic sites because clearance from these areas may be delayed. One such site is the cerebrospinal fluid (CSF), ${ }^{6}$ samples of which are commonly taken as part of routine investigations in new cases of leukaemia. In support of this approach, B19 virus is known to cause meningoencephalitis, ${ }^{7}$ and one report describes chronic B19 meningitis in a child with ALL. ${ }^{6}$

\section{MATERIALS AND METHODS}

As part of routine viral screening, we examined CSF from cases of ALL at diagnosis (two were of $\mathrm{T}$ cell origin) $(\mathrm{n}=14)$, acute myeloblastic leukaemia $(\mathrm{AML})$ at diagnosis $(\mathrm{n}=2)$, benign intracranial hypertension $(\mathrm{BIH})$ with ventriculoperitoneal shunt $(\mathrm{n}=10)$, and hydrocephalus with ventriculoperitoneal shunt $(n=13)$ presenting during an outbreak of acute parvovirus B19 in the UK using nested polymerase chain reaction (PCR) specific for the B19 NSl gene. ${ }^{7}$ Positive samples were confirmed using a nested PCR specific for the B19 VPl gene, as described previously. ${ }^{7}$ The patients with leukaemia had an overall mean age of 46.9 months (range, 18-86 months). CSF was taken during routine diagnostic and therapeutic lumbar puncture. AntiB19 IgM and IgG antibodies were detected in serum and CSF by western blot (Mikrogen, Martinsried, Germany). Serum cytokines/chemokines were measured in duplicate using the Bioplex protein array system (BioRad, Hemel Hempstead, Hertfordshire, UK), according to the manufacturer's instructions. This is a novel multiplexed, particle based, flow cytometric assay, which uses specific monoclonal antibodies linked to microspheres incorporating distinct proportions of two fluorescent dyes. Our assay was customised to detect and measure tumour necrosis factor $\alpha(\mathrm{TNF} \alpha)$, interferon $\gamma$ (IFN $\gamma$ ), interleukin $1 \beta$ (IL-1 $\beta$ ), IL-5, IL-6, IL-13, granulocytemacrophage colony stimulating factor (GM-CSF), and macrophage chemoattractant protein 1 (MCP-1). Mediators were included in this assay according to present knowledge of those upregulated during B19 infection, ${ }^{8}$ and those which may contribute to the pathogenesis of acute leukaemia. ${ }^{910}$

\section{RESULTS}

The B19 NS1 gene was detected in the CSF of four of 16 patients with acute childhood leukaemia at presentation, but was not detected in the CSF of the patients with either BIH or hydrocephalus (Yates-corrected $\chi^{2}$ value, 3.97; $p=0.046$;

Abbreviations: ALL, acute lymphoblastic leukaemia; AML, acute myelogenous leukaemia; $\mathrm{BIH}$, benign intracranial hypertension; CSF, cerebrospinal fluid; GM-CSF, granulocyte-macrophage colony stimulating factor; IL, interleukin; MCP, macrophage chemoattractant protein; PCR, polymerase chain reaction; TNF, tumour necrosis factor 
odds ratio, 16.92; confidence interval, 1.03 to 77.18). All four positive patients had normal amounts of CSF leucocytes and protein, and had neither symptoms suggestive of meningoencephalitis nor evidence of central nervous system (CNS) leukaemia, either preceding or following the diagnosis of their acute leukaemia. The B19 VPl gene was detected in CSF from two of the three patients tested, and in the serum of one of the three patients. The overall mutation rate of $\mathrm{B} 19$ virus is approximately $1 \%$, with the NSI gene more highly conserved than the capsid genes; this may explain the CSF results in case 4 , but not the day 15 serum results in case 2 , which were reproducible. However, mutations do occur within the NSI gene. Cell culture for virus isolation on these and the other 12 patients was negative.

All four positive patients were significantly anaemic at presentation (table 1), and in case 1, erythroid progenitors were completely absent from the bone marrow. Stored serum was available from three of the four patients, all of whom had evidence of serum anti-B19 IgM, confirming acute infection. Anti-B19 NSI IgG, thought to be associated with the severity of B19 infection, was detected in the CSF and/or serum of three of the four patients. Table 1 shows the clinical, haematological, and genetic data, along with B19 markers and serum cytokines on these four patients. A similar profile of mediators was seen in the serum of each of the three patients tested, in that TNF $\alpha$, IFN $\gamma$, IL-6, GM-CSF, and MCP1 were detectable, whereas IL-1 $\beta$, IL-5, and IL- 13 were not (table 1). These cytokines were also measured in the serum of 19 healthy normal controls, and mean concentrations $(\mathrm{pg} / \mathrm{ml})$ were as follows; IL- $1 \beta$ (0), IL-5 (0), IL-6 (2.14; range, $0-30.91), \operatorname{IL}-13(0), \operatorname{IFN} \gamma(0.80$; range, $0-8.62)$, TNF $\alpha$ (1.62; range, $0-12.32)$, GM-CSF (13.73; range, 0-67.26), and MCP-1 (0.83; range, 0-11.14).

\section{DISCUSSION}

We have demonstrated a significant association between the presence of parvovirus B19 DNA in the CSF of four of 16 patients with acute leukaemia at presentation compared with normal controls (BIH and hydrocephalus) $(p=0.046)$.

We have recently shown that $94 \%$ of patients with acute symptomatic parvovirus B19 carry HLA-DRB1 alleles with a neutrally charged glutamine (Q) at position 10 and a positively charged lysine $(\mathrm{K})$ at position 12 within the first hypervariable region. ${ }^{11}$ This includes HLA-DRB1 alleles *01, $* 04, * 07, * 09, * 15$ and $* 16$. Polymorphism in the first

Table 1 Clinical, haematological, and genetic data, along with B19 markers and serum cytokines on four cases of new onset of parvovirus B19 associated acute leukaemia

\begin{tabular}{|c|c|c|c|c|c|c|c|c|}
\hline & Case 1 & \multicolumn{3}{|c|}{ Case 2} & \multicolumn{2}{|c|}{ Case 3} & \multicolumn{2}{|c|}{ Case 4} \\
\hline Age & 7 years 2 months & \multicolumn{3}{|c|}{6 years 11 months } & \multicolumn{2}{|c|}{2 years 3 months } & \multicolumn{2}{|c|}{1 year 6 months } \\
\hline Sex & $\mathrm{F}$ & \multicolumn{3}{|c|}{$\mathrm{F}$} & \multicolumn{2}{|c|}{$\mathrm{M}$} & \multicolumn{2}{|c|}{$\mathrm{F}$} \\
\hline Diagnosis & Common ALL & \multicolumn{3}{|c|}{ Common ALL } & \multicolumn{2}{|c|}{ Null cell ALL } & \multicolumn{2}{|c|}{ M7 AML } \\
\hline Clinical details & $\begin{array}{l}4 \text { week history of pallor and } \\
\text { scalp swelling }\end{array}$ & \multicolumn{3}{|c|}{$\begin{array}{l}5 \text { week history of flitting } \\
\text { polyarthralgia, tiredness, } \\
\text { lethargy, fever; } 3 \text { day } \\
\text { history of rash; pallor, purpura, } \\
\text { lymphadenopathy, } \\
\text { hepatosplenomegaly }\end{array}$} & \multicolumn{2}{|c|}{$\begin{array}{l}3 \text { week history of cough, } \\
\text { lethargy, fever and pallor; } \\
\text { lymphadenopathy, } \\
\text { hepatosplenomegaly }\end{array}$} & \multicolumn{2}{|c|}{$\begin{array}{l}5 \text { week history of unwell, pallor, } \\
\text { rash, anorexia, weight loss, } \\
\text { leg pain; upper respiratory tract } \\
\text { infection, and pancytopenia } \\
2 \text { weeks ago; pallor, fever, } \\
\text { purpura, hepatosplenomegaly }\end{array}$} \\
\hline CNS disease & No & \multicolumn{3}{|c|}{ No } & \multicolumn{2}{|l|}{ No } & \multicolumn{2}{|l|}{ No } \\
\hline $\mathrm{Hb}$ & $5.4^{*}$ & \multicolumn{3}{|l|}{3.0} & \multicolumn{2}{|l|}{$5.5 \dagger$} & \multicolumn{2}{|l|}{4.2} \\
\hline WCC & $2.3^{*}$ & \multicolumn{3}{|l|}{17} & \multicolumn{2}{|c|}{60 (neutropenia) $\dagger$} & \multicolumn{2}{|l|}{1.1} \\
\hline Platelets & $130^{*}$ & \multicolumn{3}{|l|}{11} & \multicolumn{2}{|c|}{$411 \dagger$} & \multicolumn{2}{|l|}{58} \\
\hline CSF leucocytes/protein & Normal & \multicolumn{3}{|c|}{$\begin{array}{l}\text { Normal } \\
\text { Lymphoblasts }\end{array}$} & Norm & & Norn & \\
\hline $\begin{array}{l}\text { Peripheral blood } \\
\text { smear }\end{array}$ & Lymphoblasts & Lympl & blasts & & Lymp & & Myel & \\
\hline Bone marrow & Lymphoblasts-CD10+, CD19+ & Lympl & blasts - & D10+, CD19+ & Lymp & & Myel & \\
\hline Cytogenetics & $\begin{array}{l}53 X X,+X,+6,+14,+17,+18 \\
+21,+21 / 46 X X\end{array}$ & $\begin{array}{l}50-5 \\
{[\mathrm{cp} 9]}\end{array}$ & $\begin{array}{l}\left\langle X_{1}+X_{1}+\angle\right. \\
6 X^{\prime}{ }^{\prime}\end{array}$ & $+14,+21,+21$ & $46 X Y$ & & $\begin{array}{l}50 \times x \\
11: 14\end{array}$ & $\begin{array}{l}+9,+\operatorname{der}(14) \dagger \\
\left.q^{3} 2\right)^{3} / 46 X^{17}\end{array}$ \\
\hline HLA-DR & *07 & $* 07 / *$ & & & ${ }^{*} 15 /$ & & ${ }^{*} 040$ & \\
\hline Treatment & UKALL '97 & UKAL & & & UKAL & & AML & \\
\hline Outcome & Remission & Remis & & & $\begin{array}{l}\text { Death } \\
\text { owin } \\
\text { montl } \\
\text { chem }\end{array}$ & $\begin{array}{l}\text { g chemotherapy } \\
\text { acterial sepsis, } 7 \\
\text { r starting } \\
\text { apy }\end{array}$ & Deatl & to $\mathrm{AML}$ relapse \\
\hline B19 markers & & & & & & & & \\
\hline Specimen & CSF & CSF & Serum & Serum & CSF & Serum & CSF & Serum \\
\hline $\begin{array}{l}\text { Days after diagnosis } \\
\text { of leukaemia }\end{array}$ & 1 & 3 & & 22 & 3 & 29 & 1 & 6 \\
\hline NSl gene & + & + & - & - & + & - & + & - \\
\hline VP1 gene & NT & + & + & - & + & - & - & - \\
\hline$V P 1 / 2 \lg M$ & - & - & $+/-$ & $+/-$ & - & + & - & $+/-$ \\
\hline $\mathrm{VPl} / 2 \lg G$ & + & + & + & + & + & + & + & + \\
\hline NS1 lgG & + & - & + & + & - & - & - & + \\
\hline Serum cytokines $(\mathrm{pg} / \mathrm{ml}$ & & & & & & & & \\
\hline TNF $\alpha$ & NT & 3.59 & & & & 126.18 & & 15.74 \\
\hline $\mathrm{IFN} \gamma$ & NT & 14.83 & & & & 41.18 & & 15.94 \\
\hline IL-1 $\beta$ & NT & - & & & & - & & - \\
\hline IL-5 & NT & - & & & & - & & - \\
\hline IL-6 & NT & 1904 & & & & 33.45 & & 750.40 \\
\hline IL-13 & NT & - & & & & - & & - \\
\hline GM-CSF & NT & 3800 & & & & 69.81 & & 34.93 \\
\hline MCP-1 & NT & 138.6 & & & & 107.48 & & 24.98 \\
\hline
\end{tabular}

*Blood taken three months before the diagnosis of common ALL. +Blood taken before administration of blood products.

ALL, acute lymphoblastic leukaemia; CNS, central nervous system; CSF, cerebrospinal fluid; GM-CSF, granulocyte-macrophage colony stimulating factor; Hb, haemoglobin; IFN, interferon; IL, interleukin; MCP, macrophage chemoattractant protein; NT, not tested; TNF, tumour necrosis factor; WCC, white cell count. 
hypervariable region of the DRBl molecule has been associated with other clinical conditions, ${ }^{12}{ }^{13}$ and we have speculated that it may be a crucial region in the immune response to parvovirus B19. It is interesting that each of the four patients in our present study carried at least one allele with the same polymorphism in this region. Although only a small number, it provides further support to the hypothesis that the immune response is an important factor in the pathogenesis of B19 associated acute leukaemia.

Greaves has long postulated that infection plays a part in childhood ALL. ${ }^{14}$ Epidemiological (for example, population mixing, space time clustering, seasonality, etc) and biological (for example, association with particular HLA alleles) data suggest a role for infectious agents at some stage in the aetiology of childhood ALL. Recent studies have suggested in utero initiation of preleukaemic clones, ${ }^{15}$ which require one or more subsequent genetic and/or proliferative event(s) to produce the leukaemia-certainly in ALL, and maybe also in AML, during early childhood. Although it is possible that infection may play a role in initiation of the initial genetic rearrangements, there is increasing evidence that its major role lies at the later proliferative stage. The host response to infection may play an additional role in allowing proliferation of the premalignant clone.

"Although only a small number, it provides further support to the hypothesis that the immune response is an important factor in the pathogenesis of B19 associated acute leukaemia"

The host response during B19 associated acute leukaemia may provide insights into possible mechanisms by which the virus may at least precipitate the overt leukaemia. Serum concentrations of TNF $\alpha$ and IFN $\gamma$ are typical of symptomatic acute B19 infection. ${ }^{8}$ Greatly raised serum concentrations of IL-6 and GM-CSF have previously been documented at the onset of acute leukaemia. ${ }^{10}$ The chemokine MCP-1 is released by leukaemic cells; it is chemotactic for monocytes and induces the tumoricidal activity of monocytes, and is thus a possible host defence against neoplasia. ${ }^{16}$ B19 virus infection is associated with the suppression of erythroid elements in the bone marrow, along with immune cell proliferation and upregulation of key mediators, such as GMCSF. Such mechanisms may play an important role in the conversion of preleukaemic clones to an overt leukaemia.

\section{Take home messages}

- Parvovirus B19 DNA was found in the cerebrospinal fluid of four of 16 patients with acute leukaemia at presentation, but was absent from normal controls

- Erythroid suppression and immune cell proliferation are both associated with B19 infection and may also be important in the pathogenesis of acute leukaemia

\section{ACKNOWLEDGEMENTS}

F Barah performed testing for B19 markers and was funded by the ORS awards scheme and an FC Moore award from the University of Manchester. V Cunniffe performed testing for cytokines and was funded by the Chronic Fatigue Syndrome Research Foundation. We thank Mr A Liversage of BioRad, UK, for assistance with cytokine testing protocols and Dr D L Mattey for advice on the discussion of HLA-DRB1 alleles.

\section{Authors' affiliations}

J R Kerr, V S Cunniffe, Department of Microbiology, Royal Brompton Hospital, Imperial College London, Sydney Street, London SW3 6NP, UK

F Barah, P J Vallely, G M Cleator, Department of Virology, University of Manchester, M13 9WL, UK

J Smith, Tissue Typing, Harefield Hospital, Middlesex, UB9 6JH, UK

A M Will, R F Wynn, R F Stevens, O B Eden, Department of Paediatric Haematology/Oncology, Central Manchester and Manchester Children's University Hospital Trusts, Manchester M20 4BX, UK

G M Taylor, Department of Immunogenetics, Central Manchester and Manchester Children's University Hospital Trusts, Manchester M13 9WL, UK

Correspondence to: Dr J R Kerr, Department of Microbiology, Royal Brompton Hospital, Imperial College London, Sydney Street, London SW3 6NP, UK; j.kerr@ic.ac.uk

Accepted for publication 17 May 2003

\section{REFERENCES}

1 Heegaard ED, Madsen HO, Schmiegelow K. Transient pancytopenia preceding acute lymphoblastic leukaemia (pre-ALL) precipitated by parvovirus B19. Br J Haematol 2001;114:810-13.

2 Savasan S, Ozdeir O. Parvovirus B19 infection and acute lymphoblastic leukaemia. Br J Haematol 2003;120:166-71.

3 Petrella T, Bailly F, Mugneret F, et al. Bone marrow necrosis and human parvovirus associated infection preceding a $\mathrm{Ph} 1+$ acute lymphoblastic leukaemia. Leuk Lymphoma 1992;8:415-19.

4 Lee SM, Kim DG, Bang D. Persistent erythema infectiosum-like rash as a prodrome of acute lymphoblastic leukaemia. Pediatr Dermatol 1994:11:156-9.

5 Heegaard ED, Jensen L, Hornsleth A, et al. The role of parvovirus B19 infection in childhood acute lymphoblastic leukemia. Pediatr Hematol Oncol 1999; 16:329-34

6 Sinclair JP, Croxson MC, Thomas SM, et al. Chronic parvovirus B19 meningitis in a child with acute lymphocytic leukemia. Pediatr Infect Dis J 1999; 18:395-6.

7 Barah F, Vallely PJ, Chiswick ML, et al. Association of human parvovirus B19 infection with acute meningoencephalitis. Lancet 2001;358:729-30.

8 Kerr JR, Barah F, Mattey DL, et al. Serum tumour necrosis factor- $\alpha$ (TNF- $\alpha$ ) and interferon- $\gamma$ (IFN- $\gamma$ ) are detectable during acute and convalescent parvovirus B19 infection and are associated with prolonged and chronic fatigue. J Gen Virol 2001;82:3011-19.

9 Sugiyama H, Inoue K, Ogawa H, et al. The expression of IL-6 and its related genes in acute leukaemia. Leuk Lymphoma 1996;21:49-52.

10 Elbaz O, Shaltout A. Implication of granulocyte-macrophage colony stimulating factor (GM-CSF) and interleukin-3 (IL-3) in children with acute myeloid leukaemia (AML); malignancy. Hematology 2001;5:383-8.

11 Kerr JR, Mattey DL, Thomson W, et al. Association of symptomatic acute parvovirus B19 infection with HLA class I and class II alleles. J Infect Dis 2002; 186:447-52.

12 Mierau R, Dick T, Bartz-Bazzanella P, et al. Strong association of dermatomyositis-specific Mi-2 autoantibodies with a tryptophan at position 9 of the HLA-DR beta chain. Arthritis Rheum 1996:39:868-76.

13 Vrethem M, Ernerudh J, Cruz M, et al. Susceptibility to demyelinating polyneuropathy in plasma cell dyscrasia may be influenced by amino acid position 9 of the HLA-DR beta chain. J Neuroimmunol 1993;43:139-44.

14 Greaves MF. Aetiology of acute leukaemia. Lancet 1997;349:344-9.

15 Wiemels JL, Cazzaniga G, Daniotti M, et al. Prenatal origin of acute lymphoblastic leukaemia in children. Lancet 1999;354:1499-503.

16 Gerard C, Rollins BJ. Chemokines and disease. Nat Immunol 2001;2:108-15. 